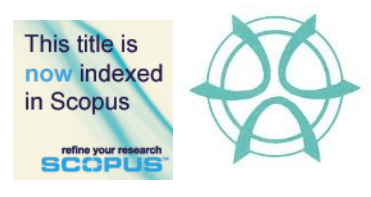

PLANNING MALAYSIA:

Journal of the Malaysian Institute of Planners

VOLUME 17 ISSUE 1 (2019), Page 196 - 204

\title{
SPILLOVERS EFFECT IN ASIAN PROPERTY PORTFOLIO MARKETS
}

\author{
Muhammad Najib Razali ${ }^{1}$ \& Muhammad Yusaimi Hamid ${ }^{2}$ \\ ${ }^{1,2}$ Faculty of Geo-information and Real Estate \\ UNIVERSITI TEKNOLOGI MALAYSIA
}

\begin{abstract}
This paper is to study the spillovers effect in Asian property portfolio market to assess the level of volatility. This is important due to investors increasingly set to go international on real estate market. The increase of integration of property portfolio markets from the perspectives of cross border has put the importance to assess the spillovers effect in particular Asian property portfolio market. The impact of a financial crisis has put paramount interest for investor and policy maker to know the level of volatility and consequently the effect on spillovers. In addition, real estate market has also been the subject of financial risk analysis. The globalisation process has given impact to the integration of market which consequently deregulation and financial market liberalisation. Therefore, spillovers effect among Asian portfolio market need to be assessed to increase the level of information as well as transparency of portfolio market.
\end{abstract}

Keyword: Asian, integration, property, portfolio, volatility, spillovers 
PLANNING MALAYSIA

Journal of the Malaysia Institute of Planners (2019)

\section{INTRODUCTION}

The significance and performance of the Asian-securitised real estate sector justifies interest from global investors. Asian markets exhibited a very different behaviour compared to the other mature markets. The correlation between listed real estate securities and the relative broad stock market proved to be remarkable and approximately stable. Consequently, the Asian region offers many opportunities for investment on a range of different measures. Being amongst the fastest growing economies through the continent, Asia has several national markets that have reached majority in terms of market complexity transparency and competitiveness (Nguyen, 2011). According to research report by CBRE (2015), China and Singapore are two major countries as a source of capital at global investment. Strong growth and outstanding risk-adjusted performance by securitised real estate Asian markets has recently made international investors increasingly interested in real estate allocations in their portfolio.

According to the Steineit and Crowe (2001), listed property companies have become a progressively vital investment vehicle in Asia and internationally. This is because listed property companies have been used to obtain a broad range of other specific features such as return enhancement, secure dividend stream, inflation hedging and tax efficient cash flows generation. Asian also continue to play a major role in global investment particularly on source of capital. Some countries in Asian also introduced REITs such as Korea, Hong Kong, Singapore, Malaysia and Japan. However, most of the Asian countries property market are still on developing stage. As such, Asian markets may experience higher volatility compared to other mature markets (Razali, 2015).

Previous studies have reported that correlations between international stock returns, and to a lesser extent, between securitized real estate market returns (Liow, 2008) have increased in the context of globalization and financial integration. The market integration or segmentation does have effects for the relationship and linkages between difference markets. Furthermore, the market integration could also affect long term implications from the co-integration of the market. If markets are co-integrated, it implies the diversification opportunities between the markets are reduced in comparison to markets that are segmented. Financial deregulation, integration of national capital markets in periods of financial contagion have been found in strengthening interrelated markets across global property security markets. Consequently, real estate players such as global investors, fund managers and policymakers should care how this asset class behaves in times of crisis to volatility causality and contagion effect in international financial markets, because securitized real estate markets may have different patterns of causality and contagion due to the underlying asset. Thus, real estate can serve as a factor of production and as an investment tool. Therefore, fund managers need to be active in finding additional sources of diversification. Consequently, the integration of the market has also created 
Muhammad Najib Razali \& Muhammad Yusaimi Hamid

Spillovers Effect in Asian Property Portfolio Markets

uncertainty among the markets which create volatility and spillovers conditions. Spillovers is a condition whereas the financial situation in one country able to give significant impact to other country(s).

This study also add academic value to the contagion and market integration literature, and this paper differs from other similar papers regarding interdependence and contagion of listed property companies. This especially arose after the 1997 Asian Financial Crisis (AFC) as well as the GFC. For instance, Ghysels and Seon (2005) examined the contagion effect of the Asian stock market during and after the AFC. Another study done by Caporale, Cipollini and Demetriades (2005) also examined a similar subject matter. Nguyen (2011) measured the volatility spillover of Asian listed property companies by segregating between developed and emerging markets. Razali (2015) has study the dynamics of volatility for Asian listed property companies during the global crisis. Nevertheless, how far the volatility level will effect in term of spillovers among pan-Asian countries' listed property companies? Therefore, this study investigates the level of volatility within the Asian real estate market over the period from 2000 to 2015. As the market has become more integrated it is therefore important to assess the spillover effect among pan-Asian countries.

\section{RESEARCH BACKGROUND}

Real estate markets are highly related to the financial markets; thus financial market volatility will impact on the risk level in the property securitised market. Market volatility is very important to policy makers. This is due to the fact that volatility levels will have a significant impact on the condition of the market. Volatility is part of the macro prudential assessment of market performance. Relatively higher levels of volatility indicate higher uncertainty regarding future cash flows and discount rates enhance future economic conditions (Danielsson, Valenzuela, \& Zer, 2016). They added such high volatility can therefore be seen by forward looking economic agents as a signal of the increased risk of adverse future outcomes and a pending crisis. Therefore, understanding the volatility and property security market is crucial for leverage decisions. Significant changes in volatility will have a major impact on investors in terms of risk and return. Volatility is associated with unpredictability and uncertainty, and has a significant impact on performance as well as variance risk (Razali 2015). Investors will see volatility as a major indicator for market symptom disruption and condition of capital markets.

Thus, this paper focus on the spillover literature that underpins the empirical investigations in this study. In the cases of spillovers across different asset classes within a domestic economy, Shiller and Beltratti (1992) find a positive correlation between stock returns and bond yields. Ehrmann and Fratzcher (2004) find stock prices react strongly to monetary policy shocks in the USA. On international spillovers, many studies have focused on individual asset 
PLANNING MALAYSIA

Journal of the Malaysia Institute of Planners (2019)

prices in isolation. For example, King, Sentana and Wadhwani (1994) detect some conditional return and volatility spillovers from the US to the Japanese and UK stock markets. Andersen and Bollerslev (1998) find strong conditional return and volatility spillovers in foreign exchange markets. Bae, Karolyi and Sulrtz (2003) report that exchange rate linkages strengthened during financial crises for several emerging markets.

Towards this direction, Diebold and Yilmaz (2009) developed return and volatility spillover indices over rolling sub-sample windows to analyze contagion and interdependence across national stock markets based on the Cholesky factor identification of VARs. Diebold and Yilmaz (2012) have provided an unconditional directional volatility spillover study to the US financial markets to shed light on the nature of cross-volatility transmission during the recent GFC. Since then, the generalized spillover index methodology has attracted significant attention and has been applied successfully in many studies, which include Zhou, Zhang and Zhang (2012) on the Chinese and world equity markets; Antonakakis (2012) on Euro and major exchange rates over the periods from January 1986 to December 2010; Duncan and Kabundi (2011) on the volatility spillovers across South African currencies, bonds and equities from October 1996 to June 2013; Samanta and Zadeh (2012) on the return and volatility spillovers across international gold, oil, Dow Jones stock and real exchange rate (dollar) during January 1989 through September 2009. Recently, Louzis (2013) examines the return and volatility spillovers among money, stock, foreign exchange and bond markets of the euro areas from January 2000 to July 2012. Other notable studies are sovereign bond yield spreads (Antonakakis \& Vergos, 2013; Alter and Beyer, 2014), as well as public real estate markets (Liow, 2013; 2014).

The most relevant that pertaining to the real estate study is done by Liow (2013) who investigated the volatility spillover effects of daily conditional volatilities across seven European public real estate markets. Using Diebold and Yilmaz (2012)'s spillover index methodology, Liow (2013) analysed the total volatility spillover effects, as well as the time-varying and directional spillover effects across the UK, France, Germany, Netherlands, Italy, Sweden and Switzerland public property markets from January 1990 through December 2011. Among others, Liow (2013) finds that each of the European markets has influenced and has been influenced by other property markets with different intensities of volatility spillovers. The introduction and implementation of the EURO was associated with a moderate increase of volatility spillovers among the markets examined. Additionally, these markets have experienced an increase in their volatility correlation, as well as become more open around the GFC period. In a different context, Liow (2014) explores the dynamics of return comovements and volatility spillovers effects within three Greater China (GC) public real estate markets, as well as across the two GC markets (China and Taiwan), three Asia emerging markets (Malaysia, Philippines and Thailand) and 
Muhammad Najib Razali \& Muhammad Yusaimi Hamid

Spillovers Effect in Asian Property Portfolio Markets

two developed markets (the US and Japan), sampled over the period from January 1999 to December 2013, with moderate degree of return co-movements and volatility spillover effects within and across the GC region reported in this study.

\section{DATA AND METHODOLOGY}

The spillover effect analysis will be based on volatility and analysed for each of the pan-Asian listed property companies. This research will covers the listed property companies' performance in pan Asian countries over the period from 2000 to 2015. The countries involve are Singapore, Malaysia, Japan, Taiwan, Hong Kong, China, Vietnam, Indonesia, Thailand, South Korea and The Philippines. This study employed Vector Auto-Regression (VAR) which based on study done by Diebold and Yilmaz (2012). VAR is a framework which forecast error variance decompositions which is insensitive to the variable ordering. This method able to capture the "spillover" effect or interdependence among the economic variables examined. In addition, this method assess the spillovers effect in time-varying manner. It can also explicitly differentiate the directional volatility spillover measures which add to the existing total volatility spillover index measure.

As has been emphasised, the generalized VAR model allows this research to examine the decomposition of forecast error variances through analysing the total and directional volatility spillovers across all asset markets, whilst at the same time the results are invariant to the variable ordering. As a results the VAR model will construct the spillovers index. The spillover index indicates the degree of cross-market spillovers (as captured by the share of cross-market error variance in the variance decomposition) relative to the total error variance of the markets examined. This spillover effect analysis covers an aspect of a total volatility spillover index which measures what proportion of the volatility forecast error variances comes from spillovers.

\section{FINDINGS}

Table 1 presents the volatility spillover index estimation based on 10 week-ahead forecast error decomposition for the 11-asset model of the full study period. The total conditional volatility spillover index, given in the lower right corner of the table, is approximately $43.3 \%$, meaning that on average, across the emerging markets examined about $43 \%$ of the volatility forecast error variance in all 11 asset markets comes from spillover. In contrast, a relatively higher proportion (57\%) of volatility movements is caused by a purely domestic factor such the idiosyncratic dynamics of the domestic asset markets volatilities in the past. Volatility persistence values are between moderate and high (30\% to 93\%) and are the highest in most asset markets, as shown by the respective diagonal figures of Table 1. Singapore and Vietnam is clearly most sensitive to the volatility impacts from the other markets. After Singapore and Vietnam, the real estate 
PLANNING MALAYSIA

Journal of the Malaysia Institute of Planners (2019)

security markets are ranked from most indigenous to most exogenous as follows: Hong Kong 22\%, Japan 23\%, Indonesia 31\%, the Philippines 39\%, South Korea and Malaysia 49\%, Taiwan 54\%, and Thailand 63\%. Overall the 11 real estate security market's response to shocks from other markets appears to be diverse as the 11 markets are of different sizes and different levels of real estate market maturity.

\section{CONCLUSION}

This study also examined conditional international volatility spillovers of four major asset classes (public real estate, general equity, currency and bond) using a multi-asset class (i.e. 32 assets) VAR model across eight emerging countries based on Diebold \& Yilmaz (2012)'s generalized spillover index methodology. Since the two crises (GFC and EDC) are exogenous to emerging markets, we focus on how sensitive emerging markets and which asset classes of emerging markets are to these crisis shocks.

Based on the results, the existence of interdependence level across the Asian markets are high. Moreover, this study inclines to conclude that Asian's property market were not spared from the financial crisis such as Global Financial Crisis and Asian Financial Crisis.

Overall, this chapter discussed on the implications of this study into several aspects namely knowledge literature and methodology, theoretical, industry and investors' perception to give overall insight the contribution of this study from different point of stakeholders' view. More importantly, this study able to inform the investors in term strategic-making of their investment strategy to pan-Asian countries. It can be seen over the past decade, several pan-Asian countries have showed high spillovers effect such as Malaysia, Indonesia, Japan, Taiwan and The Philippines has great influence in property portfolio investment to other countries. Although some of these countries showed low performance in term of Sharpe ratio and high volatility but from the point of spillovers index it showed some effect to other country. For instance, Malaysia, Indonesia and Taiwan have showed low performance with high volatility but showed some spillovers effect for most of pan-Asian countries. 
Muhammad Najib Razali \& Muhammad Yusaimi Hamid

Spillovers Effect in Asian Property Portfolio Markets

Table 1: The conditional volatility spillover table

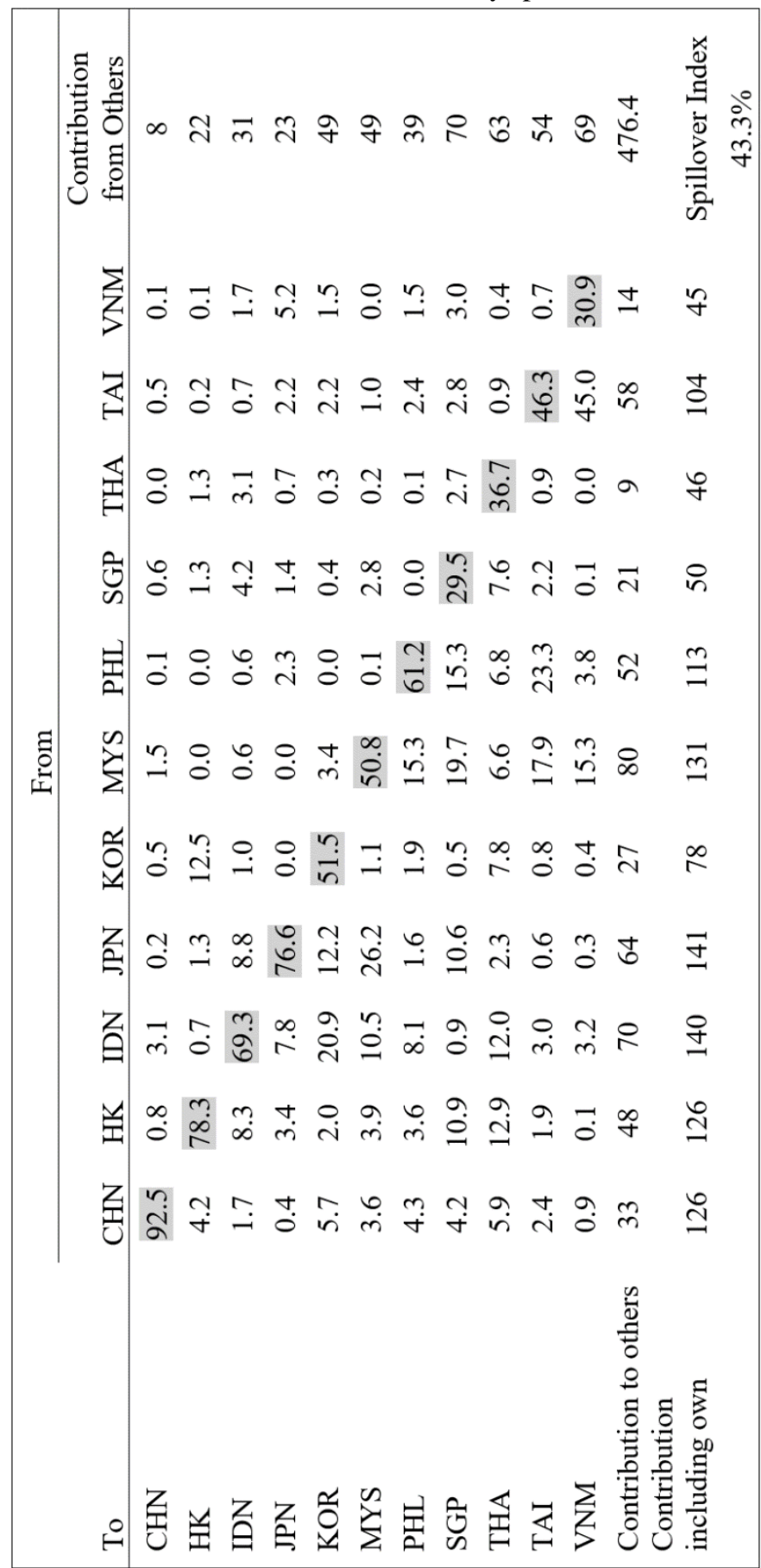




\section{REFERENCES}

Alter, A., \& Beyer, A. (2014). The dynamics of spillover effects during the European sovereign debt turmoil. Journal of Banking \& Finance, 42, 134-153.

Andersen, T., \& Bollerslev, T. (1998). Deutsche mark-dollar volatility: Intraday activity patterns, macroeconomic announcements and long run dependencies. Journal of Finance, 53, 219-265.

Antonakakis, N. (2012). Exchange return co-movements and volatility spillovers before and after the introduction of Euro. Journal of International Financial Markets, Institutions and Money 22, 1091-1109.

Antonakakis, N., \& Vergos, K. (2013). Sovereign bond yield spillovers in the Euro zone during the financial and debt crisis. Journal of International Financial Markets, Institutions \& Money, 26, 258-272.

Bae, K., Karolyi, A., \& Sulrtz, R. (2003). A new approach in measuring financial contagion. Review of Financial Studies, 16, 717 -763.

Caporale, G. M., Cipollini, A., \& Demetriades, P. O. (2005). Monetary policy and the exchange rate during the Asian crisis: Identification through heteroscedasticity. Journal of International Money and Finance, 24(1), 39-53.

CBRE. (2015). Asia Pacific Real Estate Markets Outlook. CBRE Global Research.

Danielsson, J., Valenzuela, M., \& Zer, I. (2016). Learning from history: Volatility and financial crises. The Review of Financial Studies, 31(7), 2274-2805.

Diebold, F. X., \& Yilmaz, K. (2009). Measuring financial asset return and volatility spillovers, with application to global equity markets. The Economic Journal, $119(534), 158-171$.

Diebold, F. X., \& Yilmaz, K. (2012). Better to give than to receive: Predictive directional measurement of volatility spillovers. International Journal of Forecasting, 28, 57-66.

Duncan, A., \& Kabundi, A. (2011). Volatility spillovers across South African asset classes during domestic and foreign financial crises. University of Johannesburg $\begin{array}{llll}\text { Working } & \text { Paper } & 202 . & \text { Retrieved }\end{array}$ https://econrsa.org/papers/w_papers/wp202.pdf

Erhmann, M., \& Fratzcher, M. (2004). Taking stock: Monetary policy transmission to equity markets. Journal of Money, Credit and Banking, 36(4), 719-737.

Ghysels, E., \& Seon, J. (2005). The Asian financial crisis: The role of derivative securities trading and foreign investors in Korea. Journal of International Money and Finance, 24(4), 607-630.

King, M., Sentana, E., \& Wadhwani, S. (1994). Volatility and links between national stock markets. Econometrica, 62, 901-934.

Liow, K. H. (2013). Volatility interdependence in European real estate securities markets: Who is the most influential? Journal of European Real Estate Research, 6(2), $117-138$

Liow, K. H. (2008). Financial crisis and Asian real estate securities market interdependence: Some additional evidence. Journal of Property Research, 25(2), 127-155.

Liow, K. H. (2014). The dynamics of return co-movements and volatility spillovers in Greater China public real estate markets and international linkages. Journal of Property Investment and Finance, 32(6), Forthcoming. 
Muhammad Najib Razali \& Muhammad Yusaimi Hamid

Spillovers Effect in Asian Property Portfolio Markets

Louzis, D. (2013). Measuring return and volatility spillovers in Euro area financial markets. Bank of Greece Working Paper 154.

Nguyen, T. K. (2011). The significance and performance of listed property companies in Asian developed and emerging markets. Pacific Rim Property Research Journal, 17(1), 24-47.

Razali, M. (2015). The dynamics of volatility for Asian listed property companies during the global financial crisis. Pacific Rim Property Research Journal, 21(3), 235257.

Samanta, S., \& Zadeh, A. (2012). Co-movements of oil, gold, the US dollar and stocks. Modern Economy, 3, 111-117.

Shiller, R., \& Beltratti, A. (1992). Stock prices and bond yields: Can their co-movements be explained in terms of present value model. Journal of Monetary Economics, $30(1), 25-46$.

Steinert, M., \& Crowe, S. (2001). Global real estate investment: Characteristics, optimal portfolio allocation and future trends. Pacific Rim Property Research Journal, 7(4), 223-239.

Zhou, X., Zhang, W., \& Zhang, J. (2012). Volatility spillovers between the Chinese and world equity markets. Pacific-Basin Finance Journal, 20, 247-270.

Received: $28^{\text {th }}$ October 2018. Accepted: $1^{\text {st }}$ March 2019 